\title{
Институт правительства в национальном праве
}

Воробьева Е.В.

В статье затрагиваются вопросы функций и признаков исполнительной власти, рассматриваются уникальные модели правительства в разных странах. Правительство может быть совещательным органом при индивидуальном или коллективном главе государства (монархе, президенте, революционном совете, военной хунте и т.п.). В условиях военного режима правительство может даже структурно не выделяться из состава военного совета (совета национальной безопасности и т.п.). Также рассматриваются аппарат правительства, состав аппарата, организационно-правовые формы его деятельности.

Ключевые слова: правительство; однопартийное правительство; коалиционное правительство; беспартийное правительство; аппарат правительства; институт; исполнительная власть.

Исполнительная власть (executive) определяется исследователями как «ветвь власти, которая осуществляет функции управления на основе действующих законов и иных нормативных актов» ${ }^{1}$. При этом очевидно, что исполнительная власть обладает рядом признаков, которые отличают ее от других видов власти. Никакой другой орган государственной власти не вправе принимать на себя функции и полномочия, составляющие компетенцию органов исполнительной власти. Исполнительная власть имеет универсальный характер, осуществляясь постоянно на всей территории государства. Этим исполнительная власть отличается от законодательной и судебной ветвей власти, которые могут функционировать периодически. Исполнительная власть носит подзаконный характер, поскольку государственные органы, ее реализующие, обязаны в своей деятельности руководствоваться исключительно законом и другими политико-правовыми актами. Существенный признак исполнительной власти усматривается и в ее предметном характере, который означает, что в отличие

\footnotetext{
* Воробьева Екатерина Валериевна - к.ю.н., ст. преподаватель кафедры конституционного права МГИМО (У) МИД России.

${ }^{1}$ The Concise Oxford Dictionary of Politics (Oxford University Press, 2009), ed. by Iain McLean and Alistair McMillan. P. 185.
} 
от законодательной и судебной исполнительная власть опирается на людские, материальные, финансовые ресурсы, обеспечивающие функционирование государства, опирается на армию, органы безопасности, полицию, другие государственные органы, обеспечивающие безопасность страны. Исполнительная власть представляет собой совокупность государственных органов, наделенных соответствующими полномочиями. Она носит организующий характер, имеет возможности применять для решения стоящих перед ней задач средства принуждения, должна быть легитимной и легальной.

Н.Г. Горшкова в своей диссертационной работе, на наш взгляд, удачно дала следующее определение исполнительной власти: «Это самостоятельная и независимая ветвь государственной власти, имеющая универсальный, предметный и организующий характер, выраженная системой государственных органов исполнительной власти, наделенных государственно-властными полномочиями, главное назначение которой заключается в исполнении законов и их реализации определенными методами, предусмотренными законодательством»².

Правительство как высший орган исполнительной власти представляет собой объект комплексного правового регулирования и исследуется в рамках различных отраслей юридической науки. Деятельность правительства как органа, находящегося на вершине пирамиды исполнительной власти, регулируется преимущественно нормами конституционного права. Вопросы, связанные с формированием правительства, его полномочиями, взаимодействием с главой государства и парламентом, высшей судебной инстанции и т.д., составляют конституционноправовой статус правительства.

Как отмечено, «правительство играет главную роль в разработке и формулировании основных целей политики государства, определении путей и средств их достижения и осуществления» ${ }^{3}$. Согласно определению, данному профессором С.Ю. Кашкиным, «в строгом понимании правительство - это коллегиальный орган общей компетенции, осуществляющий руководство исполнительной и распорядительной (т.е. административной) деятельностью

\footnotetext{
${ }^{2}$ Н.Г. Горшкова. Теория исполнительной власти и механизм ее осуществления. Дис ... канд. юрид. наук. Уфа, 2002. С. 14.

3 Л.М. Энтин. Правительство в зарубежных странах // Конституционное право зарубежных стран. М.: МГИМО - «Норма-Инфра-М», 2004. С. 266.
} 
в стране» ${ }^{4}$. В его состав входят руководители наиболее значительных органов центральной администрации, а иногда и представители нижестоящей администрации. Впрочем, к президентским республикам, да и к некоторым дуалистическим монархиям это определение подходит не вполне. Администрация с общей компетенцией возглавляется там не коллегиальным органом, а единолично президентом или монархом.

С точки зрения места правительства в системе исполнительной власти можно условно выделить три основные модели:

- правительство как самостоятельный орган отсутствует;

- правительство осуществляет исполнительную власть вместе с президентом;

- правительство возглавляет систему исполнительной власти.

Первую модель исследователи нередко именуют президентской, вторую - бицефальной, третью - кабинетной.

Первая из перечисленных моделей действует в США, а также в ряде стран Латинской Америки (Аргентине, Бразилии, Мексике и др.). Разновидностью этой модели можно считать систему, при которой правительство образуется как совещательный орган при президенте. Очевидно, что при такой организации исполнительной власти президенту принадлежат важнейшие полномочия в сфере исполнительной власти. Он назначает и увольняет министров, иных высших должностных лиц центральной государственной администрации, имеет широкие прерогативы в сфере иностранных дел, обороны, безопасности. Основная форма осуществления исполнительной власти в данной модели - единоличное или с участием советников решение вопросов государственного управления главой государства, а не коллективное обсуждение и решение их правительственными структурами.

Вторая модель складывается там, где исполнительную власть осуществляют и президент, и правительство (Болгария, Португалия, Польша, Финляндия, Франция и др.). В этом случае правительство создается как государственный орган, наделенный собственной компетенцией. Но прерогативы президента в сфере исполнительной власти имеют определяющий характер. Классический пример такой организации системы исполнительной власти - Франция. В Конституции Франции не сказано, что президент осуществляет исполнительную власть; не назван он и главой государства. Согласно Конституции,

${ }^{4}$ С.Ю. Кашкин. Правительство // Конституционное (государственное) право зарубежных стран. Том I / Под ред. Б.А. Страшуна. 3-е изд. М.: БЕК, 2000. С. 592. 
президент Франции следит за соблюдением Конституции, обеспечивает своим арбитражем нормальное функционирование органов государственной власти, а также преемственность государства. При этом он наделен важнейшими полномочиями в сфере исполнительной власти в целом и в отношения правительства в частности. Так, президент назначает премьер-министра, прекращает его полномочия в связи с заявлением об отставке, по представлению премьер-министра назначает членов правительства и прекращает их полномочия, подписывает ордонансы и декреты, разработанные советом министров. Президент имеет широкие полномочия по назначению на гражданские и воинские должности, в области международных отношений и в военной сфере. По меткому выражению финского исследователя Я. Нусияйнена, в «смешанной» модели организации исполнительной власти «премьер-министр дирижирует оркестром, но музыку пишет президент» ${ }^{5}$. Глава государства - президент - отвечает в основном за решение стратегических вопросов, контролирует сферы внешней политики, обороны, а премьер-министр отвечает за решение тактических задач и осуществляет оперативное, повседневное управление.

Для третьей - кабинетной или кабинетно-парламентской - модели характерно сосредоточение исполнительной власти у правительства (Венгрия, Италия, ФРГ, Эстония и др.), которое определяется в конституциях как высший орган исполнительной власти или как орган, осуществляющий исполнительную власть. При этом усиливается влияние на формирование и деятельность правительства со стороны парламента. Существенных полномочий административного и управленческого характера у президентов (монархов) в этих странах, как правило, нет, хотя, например, в Испании, согласно Конституции, министры назначаются и увольняются королем по предложению председателя правительства.

В странах, в которых организация верховной исполнительной власти не была подвержена влиянию политических традиций Запада и заимствованию западных образцов организации демократических институтов, встречаются уникальные модели правительства. Правительство может быть совещательным органом при индивидуальном или коллективном главе государства (монархе, президенте, революционном совете, военной хунте и т.п.). В условиях военного режима правительство

${ }^{5}$ J. Nousiainen. Bureaucratic tradition, semi-presidential rule and parliamentary government: The case of Finland // European Journal of Political Research. Vol. 16 № 2 (1988). P. 229-249. 
может даже структурно не выделяться из состава военного совета (совета национальной безопасности и т.п.).

Специфическая модель правительства складывается в тех странах, в которых политическая партия (порой единственная) провозглашается центром политической системы. Только такая партия вправе принимать любые политические решения, в том числе в сфере государственного управления. В этом случае правительство по сути выступает исполнительным органом правящей партии.

Наконец, в абсолютных монархиях правительство, работой которого руководит непосредственно глава государства, может быть признано высшим исполнительным и законодательным органом государственной власти.

На формирование правительства большое влияние оказывает форма правления: монархия или республика; в рамках последней речь идет о парламентской или президентской. Как справедливо отмечал видный американский политолог Аренд Лейпхарт, президентская форма правления оказывает на партийную систему и на тип исполнительной власти влияние, идущее в направлении мажоритарной, а на отношения исполнительной и законодательной властей - в направлении консенсусной модели. Президентские системы, формально отграничивая друг от друга исполнительную и законодательную власти, обычно способствуют их примерному равновесию. В то же время президентская форма способствует складыванию двухпартийной системы, так как президентство - самый большой политический «приз» и выиграть его имеют шансы лишь крупнейшие партии. Данное преимущество, которым обладают большие партии, часто остается за ними и на выборах в законодательный орган (особенно при одновременном их проведении с президентскими), даже если они проводятся по правилам пропорционального представительства. При президентской форме правления обычно формируются правительства, составленные из членов правящей партии. По сути дела, президентские республики концентрируют исполнительную власть в еще большей степени, чем это происходит при образовании парламентом однопартийного кабинета, - они сосредоточивают такую власть не просто в руках одной-единственной партии, но в руках одного-единственного лица 6 .

\footnotetext{
${ }^{6}$ См.: А. Лейпхарт. Конституционные альтернативы для новых демократий // Полис. № 5 (1995) C. 136-146.
} 
Правительство, образованное в соответствии с конституцией, считается постоянным, хотя смена состава парламента или избрание нового президента приводят к его отставке. При парламентарных и смешанных формах правления к этому приводит и вотум недоверия или отказ в доверии со стороны парламента (палаты). Правительства, образованные неконституционным или не вполне конституционным путем при смене режима, сопровождающейся к тому же изменением конституции, обычно считаются временными.

Правительство в разных странах носит различные конституционные наименования: Правительство - в Российской Федерации, Чехии, Колумбии; Кабинет - в Японии; Совет министров - в Индии; Совет министров (Правительство) - во Франции, на Кубе; Государственный совет - в Китае; Федеральное правительство - в Германии; Федеральный совет - в Швейцарии и т.д. Внутри правительства могут создаваться более узкие органы общеполитического характера - Кабинет в Великобритании; Постоянное бюро в Китае и т.П.; а также разного рода межведомственные структуры - комитеты в Великобритании, делегированные комиссии в Испании и др. Во Франции заседания правительства именуются Советом министров, когда проходят под председательством Президента, и Советом кабинета, когда председательствует премьер-министр; во втором случае основополагающие правительственные документы приниматься не могут и лишь обсуждаются. В Дании правительство под председательством королевы и с участием престолонаследника именуется Государственным советом, а под председательством премьер-министра - Советом министров.

В федеративных, а также децентрализованных унитарных государствах (таких как Испания или Италия) компетенция правительства укладывается в рамки общегосударственной (федеральной) компетенции.

Порядок формирования органов исполнительной власти в разных странах неодинаков. В странах с парламентской формой правления правительство обычно формируется из представителей победившей на выборах в парламент партии или коалиции партий. Если ни одна из партий не набрала большинства, то становятся необходимыми коалиционные переговоры между партиями, по итогам которых либо формируется правительство, либо (при неуспехе переговоров) проводятся новые парламентские выборы.

Во многих парламентских демократиях в процессе формирования правительства выделяются два основных этапа - избрание 
главы правительства и назначение министров. Например, в Германии глава правительства - канцлер избирается без прений Бундестагом по предложению Федерального президента (как правило, это лидер партии, получившей большинство голосов на выборах в Бундестаг). Избранным считается лицо, получившее большинство голосов членов Бундестага. Президент обязан назначить данное лицо на пост канцлера. Если предложенное лицо не избрано, то Бундестаг может в течение четырнадцати дней после этих выборов избрать канцлера абсолютным большинством голосов. Если в течение указанного срока избрание не состоялось, то немедленно проводится новый тур голосования, после которого избранным считается лицо, получившее наибольшее число голосов. Кандидата, получившего большинство голосов членов Бундестага, Федеральный президент должен назначить в течение семи дней после выборов, в ином случае Президент вправе в течение семи дней распустить Бундестаг. Второй этап - назначение федеральных министров. Ключевыми полномочиями при формировании правительства на данном этапе наделен канцлер. Он отбирает кандидатуры на должности министров (как правило, из числа депутатов нижней палаты парламента - представителей возглавляемой им партии, а в случае коалиционного правительства - также из числа членов иных входящих в коалицию партий) и выдвигает обязательное для Федерального президента предложение относительно их назначения (увольнения). Таким образом, канцлеру принадлежит право определения персонального состава правительства. Формально Бундестаг не имеет непосредственных правовых возможностей влиять на назначение министра или освобождение его от должности. Однако поскольку правительство нуждается в поддержке парламента, решение по кандидатурам принимается в результате согласования с представителями различных политических сил ${ }^{7}$.

В Швеции при необходимости избрания премьер-министра председатель парламента созывает совещание представителей от каждой партийной фракции в Риксдаге, после чего согласованная кандидатура передается на пленарное заседание Риксдага. Премьер-министр считается избранным, если против него не проголосует большинство депутатов. В 1978 году премьер-министром Швеции был избран лидер Народной

7 См.: А.А. Ялбулганов и М.О. Егорова. Правительство ФРГ // Правительство в зарубежных странах. М.: Ось-89, 2007. С. 103-104. 
партии, получивший всего 39 мандатов из 349, потому что большинство членов депутатского корпуса воздержалось от голосования ${ }^{8}$.

В Японии премьер-министр выдвигается из числа членов парламента; при этом такое выдвижение, как правило, предшествует всем иным делам парламента. Если палата представителей и палата советников приняли различные резолюции о выдвижении и на объединенном заседании обеих палат соглашение по кандидатуре премьер-министра не достигнуто, а также если палата советников не приняла решения в течение десяти дней после выдвижения кандидатуры премьер-министра палатой представителей (за исключением времени перерыва в работе парламента), то решением парламента становится решение его нижней палаты - палаты представителей (ст. 67 Конституции). Формально же премьер назначается на должность императором по представлению парламента (ст. 6 Конституции). Государственных министров назначает премьер-министр. Что касается императора, то он лишь подтверждает эти назначения, издавая соответствующие указы. При этом премьер-министр наделен правом отстранять государственных министров от должности по своему усмотрению (ст. 68 Конституции) ${ }^{9}$.

В Польше Президент выдвигает кандидатуру председателя Совета министров, который предлагает состав Совета министров. Президент назначает председателя Совета министров в течение 14 дней со дня первого заседания Сейма или принятия отставки предыдущего Совета министров. Президент также производит изменения в составе Совета министров по предложению председателя Совета министров.

В Португалии премьер-министр назначается Президентом после консультаций с политическими партиями, представленными в Ассамблее Республики, с учетом результатов выборов. Остальные члены правительства назначаются Президентом по предложению премьерминистра. Правительство несет ответственность перед Президентом и Ассамблеей Республики.

В Российской Федерации согласно Конституции 1993 года структура федеральных органов исполнительной власти предлагается председателем правительства и утверждается президентом. В соответствии со ст. 111 Конституции Российской Федерации председатель

\footnotetext{
${ }^{8}$ См.: М.А. Моргунова. Правительство Швеции // Правительство в зарубежных странах. С. 148.

9 См.: А.Н. Козырин. Правительство Японии // Правительство в зарубежных странах. .162-163.
} 
правительства назначается президентом Российской Федерации с согласия Государственной думы. Президент Российской Федерации при внесении в Государственную думу предложений о кандидатурах на должность председателя правительства Российской Федерации вправе представлять одного и того же кандидата дважды или трижды либо представлять каждый раз нового кандидата. После трехкратного отклонения представленных президентом кандидатур председателя правительства - независимо от того, представлялся ли каждый раз новый кандидат либо один и тот же кандидат дважды или трижды, Государственная дума подлежит роспуску ${ }^{10}$. Заместители председателя правительства Российской Федерации и федеральные министры назначаются на должность и освобождаются от должности президентом Российской Федерации по предложению председателя правительства ${ }^{11}$. Конституция Российской Федерации наделяет федеральные органы исполнительной власти правом создавать (помимо центрального аппарата) свои территориальные органы в субъектах Федерации.

Иногда конституции предусматривают обязательное представительство в правительстве определенных коллективных субъектов конституционного права либо вводят в этом отношении известные ограничения. Так, ст. 99 Конституции Бельгии установила: «Совет министров включает не более 15 членов. За возможным исключением Премьер-министра, Совет министров состоит в равном количестве из министров, изъясняющихся на французском языке, и министров, изъясняющихся на нидерландском языке». Согласно ч. 3 ст. 175 швейцарской Конституции, от одного и того же кантона нельзя избирать в Федеральный совет более одного члена.

По своему составу правительство бывает однопартийным, коалиционным и беспартийным.

Однопартийное правительство в демократическом государстве бывает при парламентарной или смешанной форме правления в том случае, когда одна из политических партий получила в результате выборов

${ }^{10}$ См.: Постановление Конституционного суда Российской Федерации от 11 декабря 1998 г. по делу о толковании положений ч. 4 ст. 111 Конституции Российской Федерации // Собрание законодательства РФ, № 52 (1998). С. 6447.

${ }^{11}$ См.: Ж.С. Тлеубаев. Соотношение конституционных полномочий президента РФ и председателя правительства РФ // Проблемы права. № 1 (2010). С. 39-43; В.В. Гончаров и С.М. Жилин. Проблемы соотношения полномочий и взаимодействия институтов президента и председателя правительства России в системе исполнительной власти и перспективы их разрешения // Право и политика. № 1 (2010). С. 8-13. 
абсолютное или близкое к нему большинство мест в парламенте или его нижней палате. Так обычно бывает в Великобритании. В президентских республиках, где имеется правительство, президент обычно формирует его из представителей своей партии, хотя иногда в тех или иных политических целях включает в него отдельных представителей из других партий. При тоталитарных политических режимах правительство обычно полностью состоит из членов руководящей партии (возможно, правда, минимальное представительство в нем партий-сателлитов, если таковые есть).

Коалиционное правительство, как правило, бывает при парламентарной или смешанной форме правления, когда ни одной из партий в итоге выборов не удалось получить в парламенте (его нижней палате) такого большинства, которое бы позволило сформировать правительство однопартийное. Другими словами, коалиционное правительство - это результат соглашения между партиями об общей правительственной программе. Правительственные партии, образовавшие коалицию, должны опираться на парламентское большинство, в состав которого могут входить и партии или независимые депутаты, в коалиции не состоящие, но ее поддерживающие. Коалиционные правительства создаются обычно в Германии, Италии. В кризисные моменты (например, в случае войны) возможно объединение в рамках правительства всех парламентских партий, создание правительства национального единства, что знаменует объединение усилий всего общества на преодоление общей опасности.

Возможно создание и правительства меньшинства, опирающегося на выборочную поддержку неправительственных партий. Оно может быть однопартийным или коалиционным, но в любом случае партии, составившие правительство, большинства в парламенте (нижней палате) не имеют. Такое правительство нередко встречается в скандинавских странах. Ему трудно принимать радикальные решения, и оно обычно ограничивается решением текущих вопросов.

Наконец, беспартийное правительство образуется в случае, если партиям в парламенте не удалось договориться о создании коалиции, а распускать парламент (нижнюю палату) нежелательно. Это правительство обычно включает специалистов, которые могут принадлежать к той или иной партии, но их партийная принадлежность в данном случае значения не имеет. Продолжительность существования такого правительства часто невелика, оно ведет текущие дела до тех пор, пока не удастся сформировать правительство на партийной основе. 
Правовую основу организации и деятельности правительства в большинстве стран образует прежде всего основной закон (конституция), в котором содержится ряд положений, касающихся формирования правительства, статуса членов правительства, отдельных полномочий, а также парламентской ответственности правительства. В большинстве демократических стран разработан отдельный законодательный корпус, регулирующий деятельность правительства. При этом организационные формы работы правительств, а также процедуры, которые складываются в процессе функционирования этого органа, редко регламентируются в конституциях. Например, специальная глава «Работа правительства» есть в конституции Швеции, однако такое решение представляет собой, скорее, исключение из общего правила. Об основной организационной форме работы правительства заседаниях - упоминается в ряде конституций (Албания, Венгрия, Латвия, Финляндия, Эстония и др.). По общему правилу формы работы правительства, его внутренняя организация и порядок деятельности закрепляются в законах о правительствах, а также в регламентах. Может быть принят документ под названием «Порядок деятельности». Например, Порядок деятельности правительства Республики Армения утвержден указом президента республики.

Заседания - форма работы, которая отвечает правовой природе правительства как коллегиального органа. Заседания правительства часто носят открытый характер. Ход работы заседаний и принятые решения освещаются средствами массовой информации. Вместе с тем в Германии проводятся закрытые заседания правительства. Без разрешения федерального канцлера не допускаются сообщения о высказываниях министров, распределении позиций в результате голосования и содержании протоколов заседаний. По общему правилу закрытыми являются и заседания правительства Эстонии. О проведении открытого заседания должно быть принято решение правительства.

В законодательстве могут быть определены: периодичность проведения заседаний; условия правомочности заседания, которые связываются с присутствием установленного числа членов правительства; круг вопросов, составляющих исключительную компетенцию заседаний; порядок принятия решений на заседании и т.д.

Аппарат правительства - понятие собирательное. Состав аппарата, организационно-правовые формы его деятельности зависят от формы правления, сложившейся в конкретной стране, от утвердившегося там 
государственно-политического режима и ряда иных факторов, отражающих национальную и историческую специфику административной деятельности в данном государстве. Аппарат правительства помогает руководителям, действующим в системе исполнительной власти, наладить взаимодействие не только с карьерными чиновниками публичной администрации, но и с другими ветвями государственной власти, содействуя тем самым реализации на практике принципа разделения власти (через взаимное информирование, поиск компромиссов при принятии правительственных решений и т.д.).

Усиление роли аппарата правительства в механизме принятия государственных и административных решений приводит к изменению характера нормативно-правового регулирования статуса этого важного звена публичной администрации. В Великобритании растет значение таких структур, как личный секретариат премьер-министра и секретариат кабинета. Во Франции при премьер-министре действуют гражданский и военный кабинеты, а входящий в состав гражданского кабинета генеральный секретариат премьер-министра координирует деятельность ведомств, готовит правительственные документы и контролирует их исполнение. В Германии возглавляемое министром Ведомство федерального канцлера разрабатывает рекомендации для главы правительства по всем направлениям работы (административным, координационным, контрольным, организационным, прогностическим и др.), готовит проекты законов и правительственных постановлений, ответы на запросы, поступающие от членов Бундестага и Бундесрата. Все чаще основы деятельности аппарата правительства закрепляются на конституционном уровне. Так, вступившая в силу 1 января 2000 года Конституция Швейцарии одну из своих статей посвящает Федеральной канцелярии. В соответствии со ст. 179 Федеральная канцелярия исполняет функции общего секретариата Федерального совета (правительства Швейцарии) и возглавляется Федеральным канцлером. В ряде стран статус аппарата правительства определяется в законах о публичной администрации. В Мексике, например, эти вопросы урегулированы в Законе о Федеральной публичной администрации 1976 года. Организация аппарата правительства может стать предметом одного или нескольких законов (в Японии это Закон об организации государственного управления 1948 года и Закон о создании канцелярии кабинета 1999 года). В некоторых странах сохраняется практика регулирования данного вопроса подзаконными актами, принимаемыми 
главой государства (главой правительства), и даже конституционными или политическими обычаями. В данном вопросе каждая страна имеет свои традиции и свою конституционно-правовую специфику.

\section{Библиографический список}

Гончаров В.В., Жилин С.М. «Проблемы соотношения полномочий и взаимодействия институтов президента и председателя правительства России в системе исполнительной власти и перспективы их разрешения» // Право и политика, № 1 (2010), стр. 8-13.

Горшкова Н.Г. Теория исполнительной власти и механизм ее осуществления. Диссертация на соискание степени кандидата юридических наук (Уфа, 2002).

Кашкин С.Ю. «Правительство» // Конституционное (государственное) право зарубежных стран, том I, под ред. Б.А. Страшуна, 3-е изд. (Москва: БЕК, 2000).

Козырин А.Н. «Правительство Японии» // Правительство в зарубежных странах, стр. 162-163.

Лейпхарт А. «Конституционные альтернативы для новых демократий» // Полис, № 5 (1995), стр. 136-146.

Моргунова М.А. «Правительство Швеции» // Правительство в зарубежных странах.

Тлеубаев Ж.С. «Соотношение конституционных полномочий президента РФ и председателя правительства РФ» // Проблемы права, № 1 (2010), стр. 39-43.

Энтин Л.М. «Правительство в зарубежных странах» // Конституционное право зарубежных стран (Москва: МГИМО «Норма-Инфра-М», 2004).

Ялбулганов А.А. и Егорова М.О. «Правительство ФРГ» // Правительство в зарубежных странах (Москва: «Ось-89», 2007), стр. 103-104.

Nousiainen J., «Bureaucratic tradition, semi-presidential rule and parliamentary government: The case of Finland» // European Journal of Political Research, vol. 16 № 2 (1988), pp. 229-249.

The Concise Oxford Dictionary of Politics (Oxford University Press, 2009), ed. by Iain McLean and Alistair McMillan. 


\section{Institution of Government in National Law (Summary)}

\section{Ekaterina V. Vorobyova*}

The article is dedicated to the institution of a Government. It touches the issue of functions and indications of executive power as well as unique models of a Government in different countries. A Government may be a deliberative body under individual or collective Head of State (monarch, president, Revolutionary Council, Military junta). During military regime even structurally a Government may not be singled out from a Military Council (Security Council etc.). The article also tackles the issue of a Government Apparatus, its membership, organizational and legal forms of its functioning.

Keywords: Government; one-party Government; coalition Government; nonpartisan Government; Government apparatus; institution; executive power.

* Ekaterina V. Vorobyova - Ph.D. in Law, senior lecturer of the Chair of Constitutional law, MGIMO-University MFA Russia. 